\title{
Intraindividual coexistence of anthropometric undernutrition and "metabolic obesity" in Indian Children: A paradox that needs action
}

Harshpal Singh Sachdev ( $\sim$ hpssachdev@gmail.com)

Sitaram Bhartia Institute of Science and Research, New Delhi, India https://orcid.org/0000-0002-4956-9391

Akash Porwal

Population Council, New Delhi, India

Avina Sarna

Population Council, New Delhi, India

Rajib Acharya

Population Council, New Delhi, India

Sowmya Ramesh

Population Council, New Delhi, India

Umesh Kapil

Institute of Liver and Biliary Sciences, New Delhi, India

Anura V. Kurpad

St John's Medical College, Bengaluru, India

\section{Research Article}

Keywords: Double burden of malnutrition, Dysglycemia, Dyslipidemia, Metabolic obesity, Overnutrition, Stunted, Undernourished, Wasted

Posted Date: December 12th, 2020

DOI: https://doi.org/10.21203/rs.3.rs-123356/v1

License: (c) (i) This work is licensed under a Creative Commons Attribution 4.0 International License. Read Full License

Version of Record: A version of this preprint was published at European Journal of Clinical Nutrition on December 12th, 2020. See the published version at https://doi.org/10.1038/s41430-021-00916-3. 


\section{Abstract}

\section{Background}

Intraindividual coexistence of anthropometrically defined undernutrition and "metabolic obesity", characterised by presence of at least one abnormal cardiometabolic risk factor, is rarely investigated in young children and adolescents, particularly in Low-and-Middle-Income-Countries undergoing rapid nutrition transition.

\section{Methods}

Prevalence of biomarkers of metabolic obesity was related to anthropometric and socio-demographic characteristics in 5-19 years old participants from the population-based Comprehensive National Nutrition Survey in India (2016-2018). The biomarkers, serum lipid-profile (total cholesterol (TC), low density lipoprotein (LDL), high density lipoprotein (HDL) and triglycerides), fasting glucose, and glycosylated hemoglobin (HbA1C), and all jointly were analysed in 22567, 23192, 25962 and 19143 participants, respectively.

\section{Results}

Overall (entire dataset), the prevalence of abnormalities was low (4.3-4.5\%) for LDL and TC, intermediate for dysglycemia (10.9-16.1\%), and high for HDL and triglycerides (21.7-25.8\%). Proportions with $\geq 1$ abnormal metabolic obesity biomarker(s) were $56.2 \%$ overall, $54.2 \%$ in thin (BMI-for-age <-2SD) and 59.3\% in stunted (height-for-age <-2SD) participants. Comparable prevalence was evident in mild undernutrition (-1 to -2 SD). Clustering of two borderline abnormalities occurred in one-third, warranting active life-style interventions. Metabolic obesity prevalence increased with BMI-for-age. Among those with metabolic obesity, only $9 \%$ were overweight/obese (>1SD BMI-for-age). Among poor participants, triglyceride, glucose and HDL abnormalities were higher.

\section{Conclusions}

A paradoxical, counter-intuitive prevalence of metabolic obesity biomarker(s) exists in over half of anthropometrically undernourished and normal-weight Indian children and adolescents. There is a crucial need for commensurate investments to address overnutrition along with undernutrition. Nutritional status should be characterized through additional reliable biomarkers, instead of anthropometry alone.

\section{Introduction}

In public health settings of most Low- and Middle-Income Countries (LMICs), anthropometry is the sole tool used to diagnose undernutrition. For individuals aged 5-19 years, underweight or thinness is defined as Body-Mass-Index (BMI)-for-age Z-score below -2, and stunting or chronic undernutrition as height-forage below $-2 \mathrm{Z}$ of the World Health Organization (WHO) growth reference [1,2]. Acute malnutrition or thinness is believed to be "usually caused by recent and severe weight loss due to extreme deprivation and famine or micronutrient-related malnutrition", while chronic undernutrition "is commonly associated with poverty, poor maternal health and nutrition, and recurring illness" [1].

According to the WHO, "the double burden of malnutrition is characterized by the coexistence of undernutrition along with overweight, obesity or diet-related Non-Communicable-Diseases (NCDs), within individuals, households and populations, and across the life-course" [3]. The Double Burden of Malnutrition (DBM) research has primarily focussed on description, etiology, and identification of "double duty actions" for interventions within households and populations, and across the life-course [4-8]. The prevalence and predictors of intraindividual stunting and overweight or obesity in LMICs has received some attention; this burden was a mere $2 \%$ in 12-15-year-old adolescents between 2003 and 2013 [9]. At the individual level, DBM has also been conceptualised as the simultaneous development of two of more types of malnutrition, for example, obesity with nutritional anaemia or any vitamin or mineral deficiencies or insufficiencies [3]. This phenomenon has also been documented in population-based surveys, both in adults [10] and children [11]. Sequentially, micronutrient undernutrition probably occurs secondary to obesity, being linked to the intake of poor-quality food, or to the inflammatory nature of adipose tissue.

In 1981, the "metabolically obese normal weight" (MONW) adult phenotype was first described as individuals in the healthy range of standard body weight (or body-mass-index) who had metabolic abnormalities commonly associated with adult-onset obesity [12]. This adult phenotype, occurs in $5 \%-45 \%$ subjects, including in LMICs, depending on the specific definition employed [13]. The MONW phenotype with at least one abnormal cardiometabolic risk factor, is also reported in up to two-thirds of children and adolescents in Iran, China and India [14-16]. However, particularly in LMICs undergoing rapid nutrition transition, there is a need to extend this MONW phenotype to anthropometrically undernourished children who could have coexisting metabolic obesity, characterised by the presence of at least one abnormal cardiometabolic risk factor. This is rarely investigated in young children and adolescents, despite our earlier report of paradoxical co-occurrence of metabolic obesity in $9 \%$ of thin children and adolescents in a fifteen-year-old dataset from urban schools in Delhi [17]. This finding is now confirmed by us in a greater proportion of thin and stunted children from a recent, quality-controlled national survey in India [18].

\section{Subjects And Methods}

This was a secondary analysis of the publicly released data from the Comprehensive National Nutrition Survey (CNNS), which was conducted between 2016 and 2018 under the aegis of Ministry of Health and Family Welfare, Government of India, in collaboration with UNICEF, India and the Population Council. Details of survey design and sampling methodology are published elsewhere [18]. Briefly, a multi-stage, population proportional to size cluster sampling was done to enrol pre-school (0-4 years) and school-age (5-9 years) children, and adolescents (10-19 years), to adequately represent the national, state, malefemale, and urban-rural population of India. Individuals with physical deformity, cognitive disabilities, chronic illness, acute febrile or infectious illness, acute injury, ongoing fever and pregnancy were excluded. Half of the participants completing anthropometry, selected by systematic random sampling, were invited to enrol for biological sampling. 
The Population Council's International Review Board (New York, USA) and ethics committee of Post Graduate Institute of Medical Education and Research (Chandigarh, India) gave ethical approval for the primary survey. Written consent from parent/caregiver for children under 10 years, consent of parent/caregiver as well as assent from adolescents (11-17 years) and written consent of adolescents above 17 years were obtained after due description of the study details in local languages.

Socioeconomic and demographic characteristics, and anthropometric data of one participant per age group were collected from each household. Wealth index, based on possession of common household items and facilities, was computed as described in National Family Health Survey-4 [19]. Trained female health workers collected all anthropometric data. Height was measured in duplicate on a height board (SECA) to the nearest $0 \cdot 1 \mathrm{~cm}$; the mean was recorded. Weight was measured once to $0.01 \mathrm{~kg}$, using a portable digital weighing scale. Quality control included weekly calibration of height board, daily calibration of weighing scale and repeat measurements by monitors in a sub-sample. The periodic inter- and intra- technical error of measurement were within the recommended range [18]. Age-sex standardized z-scores were calculated for height-for-age, weight-for-height and BMI-for-age using the WHO Growth Reference [2].

Biomarkers for metabolic obesity were evaluated only in the 5-19-years-old participants, who comprised the analytic framework. Blood samples, with information on fasting status, were collected in trace-element free tubes, the serum separated and stored frozen until analysis. Biochemical analyses were carried out by a third-party laboratory (SRL Labs, Mumbai, Gurugram and Kolkata, India). Rigorous control and monitoring systems were included in the standard operating procedures for quality assurance of biomarker data. First, an internal quality control sample was used for each batch of 20 survey samples. Second, for external quality assurance, a subset of samples was sent to other participating laboratories monthly for comparison testing. SRL laboratories participated in the BIORAD and US Centre for Disease Control external quality assurance scheme. Third, on a weekly basis, a percentage of samples were split and reanalysed, as detailed in the CNNS report [18].

Blood samples were collected after an overnight fast in $91 \%$ of participants, but glucose was estimated in only those who were fasting. Table 1 summarises the estimation methods for the analysed biochemical parameters and their cut-offs for defining abnormal values [18,20-24]. Figure 1 depicts the flow chart of the participants analysed for biochemical parameters in relation to anthropometric indices. Dyslipidemia was defined as abnormality in any of the lipid biomarkers (total cholesterol, LDL, HDL or triglyceride). Dysglycemia was defined as elevation of either fasting glucose or HbA1C. There are no internationally recognized cut-offs for defining low total cholesterol, LDL, triglyceride and HbA1c.

The metabolic-syndrome (Met-S) concept identifies a common multiple cardiovascular-risk phenotype. However, in the absence of a defined etiology, the lack of consensus on definition [20,25], and the paucity of high-level evidence addressing management in childhood, an expert panel [20] did not consider this as a separate risk entity in childhood and adolescence; instead, a combination of individual metabolic syndrome components was considered a higher risk to trigger prompt intensification of therapy. Considering the focus of our analysis, obesity and high blood pressure were not evaluated, but the remaining two components: borderline dyslipidemia (Table 1) and dysglycemia were examined, substituting elevated HbA1C for insulin resistance [20]. Similarly, we evaluated combinations of the three core biochemical abnormalities utilized in most definitions of metabolic syndrome in childhood [25] - hypertriglyceridemia, low HDL cholesterol and dysglycemia. The presence of two and all three components were labelled as 2-MetS and 3-MetS abnormalities.

Apart from summary proportions, unadjusted and adjusted (for age, sex, place of residence and wealth categories) logistic regression analyses were conducted to evaluate the relation between anthropometric Z-score categories and biomarkers of metabolic obesity.

\section{Results}

The participants were equally distributed in the 5-9 and 10-19-years age groups (Supplement Table 1). There were more boys (52\%), rural residents (55\%), Hindus (72\%) and wealthier subjects (richest two quintiles $63 \%$ ). Thinness and stunting, each, were seen in about one-fifth of participants.

Table 2 summarises the prevalence of metabolic obesity biomarkers according to BMI-for-age and height-for-age categories. Overall, in the entire dataset, the prevalence of the six biomarkers was relatively low for elevated LDL and total cholesterol (4.3-4.5\%), intermediate for glucose dysfunction (10.9-16.1\%) and high for low HDL and hypertriglyceridemia (21.7- 25.8\%). Prevalence of $\geq 1$ metabolic obesity biomarker(s), 2-MetS and 3-MetS were 56.2\%, 13.5\% and 1.9\%, respectively. The corresponding figures for thin children were $54.2 \%, 12.7 \%$ and $1.5 \%$, and for stunted participants were $59.3 \%, 15.8 \%$ and $2.1 \%$, respectively. An almost similar prevalence was observed for BMI- and height-for-age SD categories - 1 to - 2 (mild undernutrition). From the converse perspective, in the pool of all children with $\geq 1$ biomarker of metabolic obesity, the proportion of thin children was $18 \%$, stunted was $21 \%$; these proportions increased to $48 \%$ and $55 \%$ on using -1SD cut-off (Supplement Table 2). In contrast, the corresponding proportions for overweight/obese (>1SD BMI-for-age), obese (>2SD BMI-for-age) and tall (>2SD height-for-age) children were $9 \%, 3 \%$ and $1 \%$, respectively.

The prevalence of metabolic obesity biomarkers increased significantly at higher BMI-for-age categories, even after adjustment for sociodemographic factors (age, sex, residence location and wealth) (Table 2 and Figure 2). This positive association was either linear (low HDL and elevated fasting glucose) or quadratic (other biomarkers and various combinations); the upward trend became evident mostly beyond the WHO BMI-for-age median. In contrast, for heightfor-age, different patterns were observed (Table 2 and Figure 3). Height-for-age did not have a significant association with elevated fasting glucose or HbA1C and 3-MetS in both crude and adjusted models, high LDL in crude model, and high total cholesterol and low HDL in adjusted model. However, there was a significant but gentle ' $U$ ' shaped association with high triglyceride, $\geq 1$ metabolic obesity biomarker and 2-MetS, even in the adjusted model.

The association of metabolic obesity biomarkers with socio-demographic characteristics are depicted in Table 3. Total and LDL cholesterol elevation was more prevalent in wealthier subjects, while the poorer sections had higher triglyceride, fasting glucose and HDL abnormalities. With age, high LDL, low HDL and elevated $\mathrm{HbA} 1 \mathrm{C}$ were positively related, while elevated triglyceride and all combinations ( $\geq 1$ obesity biomarker, 2-MetS and 3-Mets) were negatively associated. The inverse association of triglycerides with age was not evident on substituting the lower cut-off definition for 5 -9 years ( $\geq 100 \mathrm{mg} / \mathrm{dl})$ with the

Page $3 / 15$ 
10-19 years cut-off ( $\geq 130 \mathrm{mg} / \mathrm{dl}$; data not presented). Elevated LDL, total cholesterol and serum triglycerides were more prevalent in girls whereas boys had greater $\mathrm{HDL}$, fasting glucose and $\mathrm{HbA} 1 \mathrm{c}$ abnormalities. Elevated total cholesterol was more frequent in urban settings whereas rural participants had greater abnormalities of triglyceride and $\mathrm{HbA} 1 \mathrm{C}$.

The situation with 'borderline high' cut-offs was worse (Supplement Table 3). Borderline abnormalities of total, LDL and HDL cholesterol, serum triglycerides, 2MetS and 3-MetS were documented in $14 \%, 11 \%, 42 \%, 47 \%, 29 \%$ and $5 \%$ of thin children, respectively. A similar or marginally higher prevalence was noted for stunted children and with - 1 SD cut-offs for both BMI- and height-for age. The prevalence of hypoalbuminemia and low fasting glucose was $2 \%$ and $4 \%$ for thin and $1 \%$ and $3 \%$ for stunted children, respectively.

The age stratified (5-9 and 10-19 years) prevalence of metabolic obesity biomarkers in relation to anthropometric indices is depicted in Supplement Tables 4 and 5. In the 5-9 years age group, the overall prevalence of abnormalities was notably higher for triglycerides ( $34 \%$ vs $17 \%$ ), but lower for HDL (19\% vs $25 \%$ ) and marginally lower for fasting glucose and $\mathrm{HbA} 1 \mathrm{C}$. Majority of the associations with BMI-for-age were similar to the composite 5-19 years age group. However, for height-for-age, high HBA1C, $\geq 1$ metabolic obesity biomarker and 2-MetS had a significant inverse association in the 5-9 years age group, with the highest prevalence in stunted children. In the 10-19 years age group, high LDL and total cholesterol also had a significant inverse association with height-forage in the adjusted model, but no significant associations were evident for high triglyceride, $\geq 1$ metabolic obesity biomarker and 2-MetS.

\section{Discussion}

The paradoxical contrast of metabolic obesity biomarker(s) in over half the surveyed children with conventional anthropometric diagnoses of undernutrition is intriguing, but probably an accurate reflection of the current reality in India. The data emanate from a nationally representative survey with meticulous attention to quality control procedures, especially for anthropometry and biomarkers [18]. In the earlier phase of nutrition transition, almost 15 years ago, similar findings were documented in a lower proportion (9\%) of thin children and adolescents in Delhi schools [17]. The MONW phenotype, defined as $\geq 1$ metabolic obesity biomarker and BMI-for-age between $-2 Z$ and $+1 Z$ of WHO reference, occurred in $56 \%$ of normal-weight participants. This prevalence resonates with similar reports from national surveys in Iran (41\% and 55\% dyslipidemia in 2010 and 2015, respectively) and China (63\% in 2002 among 12-18 years adolescents), urban schools in Chennai, India (65\% in 2006 among 12-19 years adolescents), and 10 cities from 9 European countries (70\% in 20062007 among adolescents), but is substantially higher than a national survey in Germany (3-13\% individual lipid abnormalities in 2003-2006 among 0-18 years old) and a regional population-survey in Denmark (4.3\% elevated fasting glucose in 2010-2015) [14-16,26-29]. However, these studies did not specifically report on the paradoxical co-existence of anthropometric undernutrition (thinness or stunting) and metabolic obesity. Progressively more metabolic abnormalities $(0,1,2$, or 3$)$ are associated with dose-dependent increases in the risk of cardiovascular disease in normal-weight adults [13]. Clustering of two and all three core biochemical abnormalities (2-MetS and 3-MetS), commonly used for defining metabolic syndrome [25], occurred in 13\% and 2\% of thin and normal-weight participants, respectively. We could not locate any specific data for comparison; however, these figures are compatible with similar clustering observed in 10\%-19\% and 1\%-2\% of normal-weight adolescents from Asia, albeit with the use of additional criteria of hypertension and abdominal obesity $[15,16,26]$.

The greater prevalence of metabolic obesity biomarkers at higher BMI categories and ages, and their relative preponderance patterning conforms with the current understanding and guidelines [14-16,20,21,26-29]. Our diagnosis of abnormal biomarkers was aligned with the internationally recommended cut-offs for identification of 5-19-year-old children with prediabetes or diabetes, and at risk of developing future cardiovascular disease [20,21]. Although the utility of these cut-offs for accurately predicting the risk of adult disease could be debated, the diagnosis of specific type(s) of existing metabolic obesity (metabolically unhealthy or metabolic dysfunction/overnutrition or cardiometabolic risk factors) cannot be disputed, particularly when the recommended [20,21] core interventions, such as dietary restrictions and active lifestyle, are directed towards inducing a negative energy balance [30]. The evaluated biomarkers are probably not reflective of short-term changes (few days) in individual metabolic profiles, especially HbA1c, which informs the glycosylation status over 3-4 months. Further, the observed prevalence of abnormal biomarkers cannot be solely attributed to rare inherited metabolic disorders like familial hypercholesterolemia and hypertriglyceridemia.

The primary cut-offs used by us underestimate the proportion of children warranting active lifestyle interventions to induce an appropriate energy balance and body composition. Considering the recommended 'borderline abnormal' lipid cut-offs for initiating action [20], nearly half (42\%-52\%) of anthropometrically undernourished (mild/moderate or greater) participants had HDL or triglyceride perturbations, while $30 \%$ had clustering of two core metabolic syndrome components. Conversely, a mere $1 \%-4 \%$ of such children had either hypoalbuminemia or hypoglycemia, the traditionally used biomarkers for clinically relevant, severe and chronic undernutrition. Thus, an overwhelming majority of these children exhibited biomarkers associated with obesity instead of clinically relevant macronutrient inadequacy. These data question the usual narrative of equating undersize in children with undernutrition or hunger, instead of being defined as a broader surrogate of developmental deprivation that may also include energy and nutrient inadequacy [31].

Similarly, apart from the relatively rare, genetic and primary endocrinal conditions, inappropriate dietary intakes and low physical activity levels may now be more important determinants of these metabolic abnormalities. Reviews on the effects of overfeeding [32] and calorie restriction [33] in humans confirm the etiological role of excess energy intake. A moderate calorie restriction (12\%) over two years in healthy normal-weight, young and middle-aged adults, improved multiple cardiometabolic risk factors well below the conventional risk thresholds [34]. Substantial evidence confirms the crucial role of physical activity and cardiorespiratory fitness in improving lipid and glucose homeostasis, both in adults and children; consequently, these life style interventions form the core of primary preventive recommendations from various professional organizations [20,35-38]. There are scant data specifically investigating the role of lifestyle interventions in MONW subjects. A recent study in Asian adults, after a diet-induced modest ( 5\%) weight loss, documented improvements in body composition, lipid profile and insulin sensitivity [39]. A 2-month life style modification trial in 12-16-year olds, comprising aerobic activity classes, diet education and behaviour modification, reduced body fat mass and improved lipid profile and inflammation [40]. Postulated mechanisms from observational evidence in adults and children also include greater relative fat accumulation, especially in the visceral adipose tissue, liver and upper body, inferior aerobic 
fitness, lower skeletal muscle mass and strength, increased screen time and diet quality - lower fruits and vegetables - and higher fructose and glucose intakes $[13,41,42]$. Mechanisms underlying a similar phenomenon in thin (underweight) subjects have not been investigated.

The aforementioned evidence thus justifies the term "metabolic obesity" for describing unambiguous biochemical aberrations; this will unequivocally alert the policy stakeholders and public about the conflicting nutritional signals originating from the thin, short and normal-weight phenotypes. We suggest restricting the terms "metabolic dysfunction" and "metabolically unhealthy" [13] for borderline biochemical abnormalities. Further, we propose the nomenclature "metabolically obese undersized" (MOU) for those who are thin or short.

India is currently undergoing a rapid nutrition transition with attendant escalation of overnutrition related NCDs [43]. Within this backdrop, we hypothesize that at the individual level, thin or stunted or normal-weight children with co-existent metabolic obesity are in positive energy balance. Whether this is a consequence of overfeeding and/or reduced physical activity, among other factors, needs investigation. Lower skeletal muscle mass and strength is likely to be an important mediator or moderator of this phenomenon. Infants, children and adolescents living in India have been characterised by a muscle-thin but adipose body composition compared with those in other countries [44,45]. The National Sample Survey Office [46] report of dietary consumption patterns in 100,547 households across India, shows that while the carbohydrate intake is high in general, the poor consume an even greater proportion of their energy intake as carbohydrates including free sugars ( $73 \%$ vs $60 \%$ in the lowest and highest socioeconomic status quintiles, respectively). However, the proportion of fat intake is greater in wealthier households ( $15 \%$ vs $27 \%$, respectively). Rural-urban comparisons show a slightly higher carbohydrate consumption by about $2-3 \%$ in rural settings across all quintiles. High carbohydrate intakes are associated with high de novo lipogenesis [47], and these dietary consumption patterns are consonant with higher $\mathrm{HbA1c}$, fasting glucose and triglyceride abnormalities in the rural setting and the poor, and the converse association for serum cholesterol [32,48].

The following limitations merit consideration. Information on all evaluated biomarkers was not available for every recruited participant; however, this did not bias the prevalence estimates (data not presented). Other important indicators of metabolic obesity (insulin sensitivity, inflammation, blood pressure) and potential explanatory factors (physical activity, body composition and muscle-strength) were either not evaluated in the survey or could not be analysed, pending the release of relevant data.

Urgent research is required on (i) Biological and mechanistic characterization of the MONW and MOU phenotypes, including an evaluation of hepatic and visceral fat distribution. (ii) Optimal public health interventions to address this intraindividual double burden of malnutrition, including focus on dietary quality and exercise plus resistance training that improves body composition without substantial weight loss. (iii) The burden of this phenotype in other geographical regions and its adult health and human capital consequences. (iv) Determining if similar phenotypes exist in the under-five age group and women planning pregnancies. In this eventuality, it is crucial to evaluate and mitigate the potential risks from consuming energy-dense therapeutic foods in wasted children [49] and dietary supplementation for pregnancies in what are believed to be undernourished populations [50].

The unexpected huge burden of metabolic obesity in Indian children, whether normal or undersized, argues strongly for commensurate investments to address overnutrition along with undernutrition. When this occurs in undersized children, considerable reflection is required on how such children should be fed, since targeting a simple negative energy balance should not be the sine qua non of the remedy. Focusing solely on anthropometry to identify at-risk (overweight/obese) individuals to prevent adult NCDs will miss $90 \%$ of those harbouring invisible metabolic threats. Lead national and global stakeholders should therefore urgently determine the optimal strategy to include these phenotypes in programmatic interventions and decide whether, in the current era, nutritional status should be defined through additional, logistically feasible and reliable biomarker(s) instead of anthropometry alone. This is also desirable from an equity and ethical perspective since poor, illiterate and vulnerable populations generally have undersized or normal-weight children. The continued reliance on undersize metrics sans biomarker(s), to quantify 'hunger' and occasionally 'near starvation' [51,52], contributes to misdirected stigma and the response thereof, primarily an enthusiastic but often blunt approach of food or nutrient(s) supplementation, with a sole focus on the 'left-hand' side of the distribution.

In conclusion, there is a paradoxical contrast of metabolic obesity biomarker(s) in over half of anthropometrically undernourished and normal-weight children and adolescents in India. Almost one-third had clustering of two metabolic dysfunctions warranting immediate, active and appropriate life-style interventions, particularly in the undersized. There is a crucial need for commensurate investments to address overnutrition along with undernutrition, biological characterization of these phenotypes, and consideration for defining nutritional status through additional reliable biomarker(s) instead of anthropometry alone.

\section{Declarations}

\section{Data Sharing}

The Ministry of Health and Family Welfare (MoHFW), Government of India owns the Comprehensive National Nutrition Survey data. The data used in this paper were released for public use by the MoHFW and United Nations Children Fund, India Country Office. The dataset is available on request from Dr. P.K. Agrawal (pkagrawal@unicef.org). The code book and the analytic code can be made available upon reasonable request to the corresponding author(s).

\section{Acknowledgements}

HSS and AVK are recipients of the Wellcome Trust/Department of Biotechnology India Alliance Clinical/Public Health Research Centre Grant \# IA/CRC/19/1/610006. AVK is also supported by the India Alliance through their Margdarshi Fellowship.

\section{Funding}


The CNNS was conducted by the Ministry of Health and Family Welfare, Government of India, and the UNICEF, with financial support from the Mittal Foundation. These secondary analyses and manuscript were not supported by any specific funding.

\section{Author contributions}

HSS conceived the idea, guided the analysis and drafted the manuscript. AP conducted all statistical analyses. AVK provided analytic insight for the National Sample Survey Office dietary consumption data. All authors were involved at every iteration of analyses and drafting, and approved the final manuscript. All authors had access to raw data.

\section{Compliance with ethical standards}

\section{Conflict of Interest}

HSS designed the draft protocol of the CNNS with consultancy support from the UNICEF, India. HSS, AS, UK and AVK were members of the Technical Advisory Committee of the CNNS, constituted by the Ministry of Health and Family Welfare of the Government of India, to oversee its conduct and analysis. HSS is a member of the World Health Organization Nutrition Guidance Expert Advisory Subgroup on Diet and Health and member of Expert Groups of the Ministry of Health and Family Welfare on Nutrition and Child Health. AS, RA, SR and AP were involved in the CNNS study implementation and main analyses. There were no other conflicts to declare.

\section{Ethical Approval}

This study was conducted according to the guidelines laid down in the Declaration of Helsinki and all procedures involving human subjects were approved by the Population Council's International Review Board (New York, USA) and ethics committee of Post Graduate Institute of Medical Education and Research (Chandigarh, India). No separate ethical approval was required or taken for this secondary analysis.

\section{References}

1. World Health Organization. Guideline: Implementing effective actions for improving adolescent nutrition. Geneva: World Health Organization; 2018; pp 159.

2. World Health Organization. Growth reference data for 5-19 years. Growth reference 5-19 years [website]. Geneva: World Health Organization; 2007 (http://www.who.int/growthref/en/, accessed 20 July 2020).

3. World Health Organization. The double burden of malnutrition: policy brief. Geneva: World Health Organization; 2017 (http://apps.who.int/iris/bitstream/10665/255413/1/WHO-NMH-NHD-17.3-eng.pdf?ua=1, accessed 20 July 2020).

4. Wells JC, Sawaya AL, Wibaek R, Mwangome M, Poullas MS, Yajnik CS, Demaio A. The double burden of malnutrition: aetiological pathways and consequences for health. Lancet. 2020;395(10217):75-88.

5. Popkin BM, Corvalan C, Grummer-Strawn LM. Dynamics of the double burden of malnutrition and the changing nutrition reality. Lancet. 2020;395(10217):65-74.

6. Peng W, Mu Y, Hu Y, Li B, Raman J, Sui Z. Double Burden of Malnutrition in the Asia-Pacific Region-A Systematic Review and Meta-analysis. J Epidemiol Glob Health. 2020;10(1):16-27.

7. Mahmudiono T, Segalita C, Rosenkranz RR. Socio-Ecological Model of Correlates of Double Burden of Malnutrition in Developing Countries: A Narrative Review. Int J Environ Res Public Health. 2019;16(19):3730.

8. Kosaka S, Umezaki M. A systematic review of the prevalence and predictors of the double burden of malnutrition within households. Br $\mathrm{J}$ Nutr. 2017; 117(8):1118-1127.

9. Caleyachetty R, Thomas GN, Kengne AP, Echouffo-Tcheugui JB, Schilsky S, Khodabocus J, Uauy R. The double burden of malnutrition among adolescents: analysis of data from the Global School-Based Student Health and Health Behavior in School-Aged Children surveys in 57 low- and middleincome countries. Am J Clin Nutr. 2018;108(2):414-424.

10. Williams AM, Guo J, Addo OY, Ismaily S, Namaste SML, Oaks BM, Rohner F, Suchdev PS, Young MF, Flores-Ayala R, Engle-Stone R. Intraindividual double burden of overweight or obesity and micronutrient deficiencies or anemia among women of reproductive age in 17 population-based surveys. Am $\mathrm{J}$ Clin Nutr. 2020;112(Suppl):468S-477S.

11. Engle-Stone R, Guo J, Ismaily S, Addo OY, Ahmed T, Oaks B, Suchdev PS, Flores-Ayala R, Williams AM. Intraindividual double burden of overweight and micronutrient deficiencies or anemia among preschool children. Am J Clin Nutr. 2020; 112(Suppl):478S-487S.

12. Ruderman NB, Schneider SH, Berchtold P. The "metabolically-obese," normal-weight individual. Am J Clin Nutr. 1981;34:1617-21.

13. Klitgaard HB, Kilbak JH, Nozawa EA, Seidel AV, Magkos F. Physiological and lifestyle traits of metabolic dysfunction in the absence of obesity. Curr Diab Rep. 2020;20(6):17.

14. Heshmat R, Hemati Z, Payab M, Hamzeh SS, Motlagh ME, Shafiee G, Taheri M, Ziaodini H, Qorbani M, Kelishadi R. Prevalence of different metabolic phenotypes of obesity in Iranian children and adolescents: the CASPIAN V study. J Diabetes Metab Disord. 2018 Oct 27;17(2):211-21.

15. Li YP, Yang XG, Zhai FY, Piao JH, Zhao WH, Zhang J, Ma GS. Disease risks of childhood obesity in China. Biomed Environ Sci. 2005;18:401-10.

16. Ramachandran A, Snehalatha C, Yamuna A, Murugesan N, Narayan KM. Insulin resistance and clustering of cardiometabolic risk factors in urban teenagers in southern India. Diabetes Care. 2007;30:1828-33. 
17. Garg P, Kaur S, Gupta D, Osmond C, Lakshmy R, Sinha S, Kapil U, Sachdev HPS. Variability of thinness and its relation to cardiometabolic risk factors using four body mass index references in school children from Delhi, India. Indian Pediatr. 2013;50:1025-32.

18. Ministry of Health and Family Welfare, Government of India, UNICEF, Population Council. Comprehensive National Nutrition Survey 2016-2018. National Health Mission, 2019. https://nhm.gov.in/showfile.php?lid=712 (accessed July 20, 2020).

19. National Family Health Survey 4. International Institute for Population Sciences (IIPS) and ICF. National Family Health Survey (NFHS-4), 2015-16: India. Mumbai; International Institute of Population Science; 2015-16.

20. Expert Panel on Integrated Guidelines for Cardiovascular Health and Risk Reduction in Children and Adolescents; National Heart, Lung, and Blood Institute. Expert panel on integrated guidelines for cardiovascular health and risk reduction in children and adolescents: summary report. Pediatrics. 2011;128(Suppl 5):S213-S256.

21. American Diabetes Association. Diagnosis and classification of diabetes mellitus. Diabetes Care. 2010;33(Suppl 1):S62-9.

22. Leite HP, Rodrigues da Silva AV, de Oliveira Iglesias SB, Koch Nogueira PC. Serum Albumin Is an Independent Predictor of Clinical Outcomes in Critically III Children. Pediatr Crit Care Med. 2016;17(2):e50-e57.

23. Kim S, McClave SA, Martindale RG, Miller KR, Hurt RT. Hypoalbuminemia and Clinical Outcomes: What is the Mechanism behind the Relationship? Am Surg. 2017;83(11):1220-1227.

24. Ogata E, Asahi K, Yamaguchi S, Iseki K, Sato H, Moriyama T, Yamagata K, Tsuruya K, Fujimoto S, Narita I, Konta T, Kondo M, Shibagaki Y, Kasahara M, Watanabe T, Shimabukuro M. Low fasting plasma glucose level as a predictor of new-onset diabetes mellitus on a large cohort from a Japanese general population. Sci Rep. 2018 Sep 17;8(1):13927.

25. Serbis A, Giapros V, Galli-Tsinopoulou A, Siomou E. Metabolic Syndrome in Children and Adolescents: Is There a Universally Accepted Definition? Does it Matter? Metab Syndr Relat Disord. 2020 Aug 13. doi: 10.1089/met.2020.0076. Epub ahead of print. PMID: 32795106.

26. Ataie-Jafari A, Heshmat R, Kelishadi R, Ardalan G, Mahmoudarabi M, Rezapoor A, Motlagh ME, Asayesh H, Larijani B, Qorbani M. Generalized or abdominal obesity: which one better identifies cardiometabolic risk factors among children and adolescents? The CASPIAN III study. J Trop Pediatr. 2014;60:377-85.

27. González-Gil EM, Cadenas-Sanchez C, Santabárbara J, et al. Inflammation in metabolically healthy and metabolically abnormal adolescents: The HELENA study. Nutr Metab Cardiovasc Dis. 2018;28(1):77-83.

28. Martin L, Oepen J, Reinehr T, Wabitsch M, Claussnitzer G, Waldeck E, Ingrisch S, Stachow R, Oelert M, Wiegand S, Holl R; APV Study Group; German Competence Network Adipositas. Ethnicity and cardiovascular risk factors: evaluation of 40,921 normal-weight, overweight or obese children and adolescents living in Central Europe. Int J Obes (Lond). 2015;39:45-51.

29. Kloppenborg JT, Fonvig CE, Nielsen TRH, Mollerup PM, Bøjsøe C, Pedersen O, Johannesen J, Hansen T, Holm JC. Impaired fasting glucose and the metabolic profile in Danish children and adolescents with normal weight, overweight, or obesity. Pediatr Diabetes. 2018;19:356-65.

30. National Heart Lung and Blood Institute. What is energy balance? In: Balance Food and Activity. Available from: https://www.nhlbi.nih.gov/health/educational/wecan/healthy-weightbasics/balance.htm\#: :text=What\%20is\%20Energy\%20Balance\%3F,physical\%20activity\%20is\%20ENERGY\%200UT. Accessed 13 November, 2020.

31. Sachdev HPS. Undersized Indian Children: Nutrients-starved or Hungry for Development? Proc Indian Natn Sci Acad 2018;84(4):867-75.

32. Bray GA, Bouchard C. The biology of human overfeeding: A systematic review. Obes Rev. 2020 Sep;21(9):e13040.

33. Most J, Tosti V, Redman LM, Fontana L. Calorie restriction in humans: An update. Ageing Res Rev. 2017;39:36-45.

34. Kraus WE, Bhapkar M, Huffman KM, Pieper CF, Krupa Das S, Redman LM, Villareal DT, Rochon J, Roberts SB, Ravussin E, Holloszy JO, Fontana L; CALERIE Investigators. 2 years of calorie restriction and cardiometabolic risk (CALERIE): exploratory outcomes of a multicentre, phase 2, randomised controlled trial. Lancet Diabetes Endocrinol. 2019;7:673-683.

35. Eckel RH, Jakicic JM, Ard JD, et al. 2013 AHA/ACC guideline on lifestyle management to reduce cardiovascular risk: a report of the American College of Cardiology/American Heart Association Task Force on Practice Guidelines. Circulation. 2014;129(25 Suppl 2):S76-S99.

36. Arnett DK, Blumenthal RS, Albert MA, et al. 2019 ACC/AHA Guideline on the Primary Prevention of Cardiovascular Disease: A Report of the American College of Cardiology/American Heart Association Task Force on Clinical Practice Guidelines Circulation. 2019;140(11):e596-e646.

37. Grundy SM, Stone NJ, Bailey AL, et al. 2018 AHA/ACC/AACVPR/AAPA/ABC/ACPM/ADA/AGS/APhA/ASPC/NLA/PCNA Guideline on the Management of Blood Cholesterol: Executive Summary: A Report of the American College of Cardiology/American Heart Association Task Force on Clinical Practice Guidelines. J Am Coll Cardiol. 2019;73(24):3168-3209. doi:10.1016/j.jacc.2018.11.002

38. American Diabetes Association. 3. Prevention or Delay of Type 2 Diabetes: Standards of Medical Care in Diabetes-2019. Diabetes Care. 2019 Jan;42(Suppl 1):S29-S33.

39. Chooi YC, Ding C, Chan Z, Choo J, Sadananthan SA, Michael N, Lee Y, Velan SS, Magkos F. Moderate Weight Loss Improves Body Composition and Metabolic Function in Metabolically Unhealthy Lean Subjects. Obesity (Silver Spring). 2018;26(6):1000-1007.

40. Kelishadi R, Hashemipour M, Sarrafzadegan N, et al. Effects of a lifestyle modification trial among phenotypically obese metabolically normal and phenotypically obese metabolically abnormal adolescents in comparison with phenotypically normal metabolically obese adolescents. Matern Child Nutr. 2010;6:275-286.

41. Van Hulst A, Ybarra M, Mathieu ME, Benedetti A, Paradis G, Henderson M. Determinants of new onset cardiometabolic risk among normal weight children. Int $\mathrm{J}$ Obes (Lond). 2020;44:781-789.

42. Nier A, Brandt A, Baumann A, Conzelmann IB, Özel Y, Bergheim I. Metabolic Abnormalities in Normal Weight Children Are Associated with Increased Visceral Fat Accumulation, Elevated Plasma Endotoxin Levels and a Higher Monosaccharide Intake. Nutrients. 2019;11:652.

Page $7 / 15$ 
43. India State-Level Disease Burden Initiative Collaborators. Nations within a nation: variations in epidemiological transition across the states of India, 19902016 in the Global Burden of Disease Study. Lancet. 2017;390:2437-60.

44. Kuriyan R, Selvan S, Thomas T, Jayakumar J, Lokesh DP, Phillip MP, Aravind JV, Kurpad AV. Body Composition Percentiles in Urban South Indian Children and Adolescents. Obesity (Silver Spring). 2018;26(10):1629-36.

45. D'Angelo S, Yajnik CS, Kumaran K, Joglekar C, Lubree H, Crozier SR, Godfrey KM, Robinson SM, Fall CH, Inskip HM; SWS Study Group and the PMNS Study Group. Body size and body composition: a comparison of children in India and the UK through infancy and early childhood. J Epidemiol Community Health. 2015;69:1147-1153.

46. National Sample Survey Office. Nutritional Intake in India: 2011-12, NSS 68th Round. New Delhi, India: National Statistical Organization. Government of India. 2014.

47. Parks EJ, Hellerstein MK. Carbohydrate-induced hypertriacylglycerolemia: historical perspective and review of biological mechanisms. Am J Clin Nutr. 2000;71:412-433.

48. Vos MB, Kaar JL, Welsh JA, Van Horn LV, Feig DI, Anderson CAM, Patel MJ, Cruz Munos J, Krebs NF, Xanthakos SA, Johnson RK; American Heart Association Nutrition Committee of the Council on Lifestyle and Cardiometabolic Health; Council on Clinical Cardiology; Council on Cardiovascular Disease in the Young; Council on Cardiovascular and Stroke Nursing; Council on Epidemiology and Prevention; Council on Functional Genomics and Translational Biology; and Council on Hypertension. Added Sugars and Cardiovascular Disease Risk in Children: A Scientific Statement from the American Heart Association. Circulation. 2017 May 9;135(19):e1017-e1034.

49. WHO, WFP, UNSCN, UNICEF. Community-based management of severe acute malnutrition. A joint statement by the World Health Organization, World Food Programme, United Nations Standing Committee on Nutrition, United Nations Children's Fund. Geneva, World Health Organization; 2007. Available from: http://www.who.int/nutrition/publications/severemalnutrition/9789280641479/en/. Accessed 20 August, 2020.

50. World Health Organization. WHO Recommendations on antenatal care for a positive pregnancy experience. Geneva: World Health Organization; 2016. Available from: https://www.who.int/reproductivehealth/publications/maternal_perinatal_health/anc-positive-pregnancy-experience/en/. Accessed 20 August, 2020.

51. von Grebmer K, Bernstein J, Mukerji R, Patterson F, Wiemers M, Ní Chéilleachair R, Foley C, Gitter S, Ekstrom K, Fritschel H. 2019 Global Hunger Index: The Challenge of Hunger and Climate Change. Bonn: Welthungerhilfe; and Dublin: Concern Worldwide, 2019. Available at: https://www.globalhungerindex.org/pdf/en/2019.pdf. Accessed on 23 August, 2020.

52. United Nations. Sustainable development Goals. Goal 2: Zero Hunger. Available at: https://www.un.org/sustainabledevelopment/hunger. Accessed on 23 August, 2020.

\section{Tables}

Table 1: Estimation methods for various biochemical parameters and their cut-offs used for specific diagnoses. 


\begin{tabular}{|c|c|c|c|}
\hline Diagnosis & $\begin{array}{l}\text { Biochemical parameter } \\
\text { (Estimation Method) }\end{array}$ & $\begin{array}{l}\text { Cut-off used to } \\
\text { define } \\
\text { abnormality }\end{array}$ & $\begin{array}{l}\text { Cut-off used to } \\
\text { define } \\
\text { "borderline" } \\
\text { abnormality }\end{array}$ \\
\hline \multirow[t]{2}{*}{ Hyper-cholesterolemia [20] } & Serum cholesterol & 5-19 years: & 5-19 years: \\
\hline & $\begin{array}{l}\text { (Spectrophotometry, cholesterol oxidase esterase } \\
\text { Peroxidase) }\end{array}$ & $\geq 200 \mathrm{mg} / \mathrm{dl}$ & $\geq 170 \mathrm{mg} / \mathrm{dl}$ \\
\hline \multirow[t]{2}{*}{ High Low Density Lipoprotein (LDL) cholesterol [20] } & Serum LDL & 5-19 years: & 5-19 years: \\
\hline & (Spectrophotometry, direct measure/ CHOD) & $\geq 130 \mathrm{mg} / \mathrm{dl}$ & $\geq 110 \mathrm{mg} / \mathrm{dl}$ \\
\hline \multirow[t]{2}{*}{ Low High Density Lipoprotein (HDL) cholesterol [20] } & Serum HDL & 5-19 years: & 5-19 years: \\
\hline & $\begin{array}{l}\text { (Spectrophotometry, direct measure - PEG/ } \\
\text { CHOD) }\end{array}$ & $<40 \mathrm{mg} / \mathrm{dl}$ & $\leq 45 \mathrm{mg} / \mathrm{dl}$ \\
\hline \multirow[t]{4}{*}{ Hyper-triglyceridemia [20] } & \multirow{4}{*}{$\begin{array}{l}\text { Serum triglyceride (Spectrophotometry, } \\
\text { enzymatic endpoint) }\end{array}$} & 5-9 years: & 5-9 years: \\
\hline & & $\geq 100 \mathrm{mg} / \mathrm{dl}$ & $\geq 75 \mathrm{mg} / \mathrm{dl}$ \\
\hline & & 10-19 years: & 10-19 years: \\
\hline & & $\geq 130 \mathrm{mg} / \mathrm{dl}$ & $\geq 90 \mathrm{mg} / \mathrm{dl}$ \\
\hline \multirow{2}{*}{$\begin{array}{l}\text { High fasting blood glucose (including diabetes mellitus) } \\
{[20,21]}\end{array}$} & \multirow{2}{*}{$\begin{array}{l}\text { Blood fasting glucose (Spectrophotometry, } \\
\text { Hexokinase) }\end{array}$} & 5-19 years: & Not available \\
\hline & & $\geq 100 \mathrm{mg} / \mathrm{dl}$ & \\
\hline \multirow{2}{*}{$\begin{array}{l}\text { High glycosylated hemoglobin (HbA1c) (including } \\
\text { diabetes mellitus) [21] }\end{array}$} & \multirow{2}{*}{$\begin{array}{l}\text { Blood HbA1C (High performance liquid } \\
\text { chromatography) }\end{array}$} & $5-19$ years: & Not available \\
\hline & & $\geq 5.7 \%$ & \\
\hline \multirow[t]{3}{*}{ Hypoalbuminemia $[22,23]$} & \multirow{3}{*}{$\begin{array}{l}\text { Serum albumin (Spectrophotometry, Bromocresol } \\
\text { purple dye } \\
\text { binding }\end{array}$} & $5-19$ years: & Not available \\
\hline & & $<3.5 \mathrm{~g} / \mathrm{dl}$ & \\
\hline & & & \\
\hline \multirow[t]{2}{*}{ Hypoglycemia (24) } & \multirow{2}{*}{$\begin{array}{l}\text { Blood fasting glucose (Spectrophotometry, } \\
\text { Hexokinase) }\end{array}$} & $5-19$ years: & Not available \\
\hline & & $<70 \mathrm{mg} / \mathrm{dl}$ & \\
\hline
\end{tabular}

Table 2: Prevalence of metabolic obesity biomarkers according to body-mass-index-for-age and height-for-age categories among children and adolescents aged 5-19 years. 


\begin{tabular}{|c|c|c|c|c|c|c|c|c|}
\hline Categories & $\begin{array}{l}\text { High total } \\
\text { Cholesterol }^{1} \\
(\%) \\
(n / N)\end{array}$ & $\begin{array}{l}\text { High LDL } \\
\text { Cholesterol }{ }^{2} \\
(\%) \\
(\mathrm{n} / \mathrm{N})\end{array}$ & $\begin{array}{l}\text { Low HDL } \\
\text { Cholesterol }^{3} \\
(\%) \\
(\mathrm{n} / \mathrm{N})\end{array}$ & $\begin{array}{l}\text { High } \\
\text { triglyceride } \\
(\%) \\
(n / N)\end{array}$ & $\begin{array}{l}\text { High fasting } \\
\text { glucose }{ }^{5} \\
(\%) \\
(n / N)\end{array}$ & $\begin{array}{l}\text { High } \\
\text { glycosylated } \\
\text { hemoglobin } \\
(\%) \\
(n / N)\end{array}$ & $\begin{array}{l}\text { At least one } \\
(\geq 1) \text { biomarker } \\
\text { of metabolic } \\
\text { obesity }(\%) \\
(\mathrm{n} / \mathrm{N})\end{array}$ & $\begin{array}{l}\text { 2-MetS } \\
(\%) \\
(n / N)\end{array}$ \\
\hline & \multicolumn{8}{|c|}{ Body-mass-index-for-age } \\
\hline Below -2SD & $\begin{array}{l}3.6 \\
(180 / 4972)\end{array}$ & $\begin{array}{l}3.4 \\
(170 / 4972)\end{array}$ & $\begin{array}{l}21.3 \\
(1061 / 4972)\end{array}$ & $\begin{array}{l}22.7 \\
(1126 / 4972)\end{array}$ & $\begin{array}{l}14.3 \\
(631 / 4400)\end{array}$ & $\begin{array}{l}11.2 \\
(560 / 4996)\end{array}$ & $\begin{array}{l}54.2 \\
(1925 / 3552)\end{array}$ & $\begin{array}{l}12.7 \\
(452 / 3552\end{array}$ \\
\hline$-2 S D$ to $-1.01 S D$ & $\begin{array}{l}3.8 \\
(293 / 7756)\end{array}$ & $\begin{array}{l}3.3 \\
(253 / 7756)\end{array}$ & $\begin{array}{l}21.1 \\
(1636 / 7756)\end{array}$ & $\begin{array}{l}24.3 \\
(1883 / 7756)\end{array}$ & $\begin{array}{l}15.2 \\
(1056 / 6955)\end{array}$ & $\begin{array}{l}11.0 \\
(858 / 7771)\end{array}$ & $\begin{array}{l}54.7 \\
(3126 / 5719)\end{array}$ & $\begin{array}{l}12.0 \\
(685 / 5719\end{array}$ \\
\hline$-1 S D$ to $-0.01 S D$ & $\begin{array}{l}4.2 \\
(303 / 7278)\end{array}$ & $\begin{array}{l}4.0 \\
(289 / 7278)\end{array}$ & $\begin{array}{l}21.8 \\
(1588 / 7278)\end{array}$ & $\begin{array}{l}25.7 \\
(1870 / 7278)\end{array}$ & $\begin{array}{l}16.4 \\
(1083 / 6622)\end{array}$ & $\begin{array}{l}9.8 \\
(727 / 7425)\end{array}$ & $\begin{array}{l}55.2 \\
(3036 / 5505)\end{array}$ & $\begin{array}{l}13.4 \\
(736 / 5505\end{array}$ \\
\hline OSD to $0.99 S D$ & $\begin{array}{l}5.9 \\
(200 / 3414)\end{array}$ & $\begin{array}{l}5.6 \\
(192 / 3414)\end{array}$ & $\begin{array}{l}22.9 \\
(783 / 3414)\end{array}$ & $\begin{array}{l}28.0 \\
(957 / 3414)\end{array}$ & $\begin{array}{l}17.7 \\
(563 / 3182)\end{array}$ & $\begin{array}{l}10.9 \\
(390 / 3549)\end{array}$ & $\begin{array}{l}58.7 \\
(1562 / 2661)\end{array}$ & $\begin{array}{l}14.7 \\
(390 / 2661\end{array}$ \\
\hline $1 S D$ to $1.99 S D$ & $\begin{array}{l}8.0 \\
(105 / 1315)\end{array}$ & $\begin{array}{l}8.1 \\
(107 / 1315)\end{array}$ & $\begin{array}{l}23.0 \\
(303 / 1315)\end{array}$ & $\begin{array}{l}34.6 \\
(455 / 1315)\end{array}$ & $\begin{array}{l}20.1 \\
(248 / 1235)\end{array}$ & $\begin{array}{l}13.4 \\
(182 / 1359)\end{array}$ & $\begin{array}{l}65.4 \\
(685 / 1048)\end{array}$ & $\begin{array}{l}20.0 \\
(210 / 1048\end{array}$ \\
\hline $2 S D$ or more & $\begin{array}{l}10.8 \\
(58 / 536)\end{array}$ & $\begin{array}{l}11.9 \\
(64 / 536)\end{array}$ & $\begin{array}{l}22.0 \\
(118 / 536)\end{array}$ & $\begin{array}{l}40.9 \\
(219 / 536)\end{array}$ & $\begin{array}{l}21.3 \\
(112 / 525)\end{array}$ & $\begin{array}{l}17.7 \\
(100 / 566)\end{array}$ & $\begin{array}{l}69.5 \\
(298 / 429)\end{array}$ & $\begin{array}{l}20.5 \\
(88 / 429)\end{array}$ \\
\hline Total & $\begin{array}{l}4.5 \\
(1139 / 25271)\end{array}$ & $\begin{array}{l}4.3 \\
(1075 / 25271)\end{array}$ & $\begin{array}{l}21.7 \\
(5489 / 25271)\end{array}$ & $\begin{array}{l}25.8 \\
(6510 / 25271)\end{array}$ & $\begin{array}{l}16.1 \\
(3693 / 22919)\end{array}$ & $\begin{array}{l}10.9 \\
(2817 / 25666)\end{array}$ & $\begin{array}{l}56.2 \\
(10632 / 18914)\end{array}$ & $\begin{array}{l}13.5 \\
(2561 / 189\end{array}$ \\
\hline $\begin{array}{l}\text { p-value }{ }^{10} \\
\text { (lineart/quadratic) }^{\text {tinee }}\end{array}$ & 0.002 & $<0.001$ & $0.064^{t}$ & $<0.001$ & $<0.001^{t}$ & $<0.001$ & $<0.001$ & $<0.001$ \\
\hline $\begin{array}{l}\text { p-value }{ }^{11} \\
\text { (lineart/quadratic) }\end{array}$ & 0.003 & $<0.001$ & $<0.001 t$ & $<0.001$ & $<0.001 t$ & $<0.001$ & $<0.001$ & $<0.001$ \\
\hline & Height-for-age & & & & & & & \\
\hline Below -2SD & $\begin{array}{l}4.4 \\
(228 / 5243)\end{array}$ & $\begin{array}{l}4.5 \\
(235 / 5243)\end{array}$ & $\begin{array}{l}25.7 \\
(1349 / 5243)\end{array}$ & $\begin{array}{l}26.4 \\
(1383 / 5243)\end{array}$ & $\begin{array}{l}16.7 \\
(784 / 4703)\end{array}$ & $\begin{array}{l}11.3 \\
(595 / 5249)\end{array}$ & $\begin{array}{l}59.3 \\
(2212 / 3730)\end{array}$ & $\begin{array}{l}15.8 \\
(589 / 3730\end{array}$ \\
\hline$-2 S D$ to $-1.01 S D$ & $\begin{array}{l}4.3 \\
(382 / 8829)\end{array}$ & $\begin{array}{l}4.2 \\
(368 / 8829)\end{array}$ & $\begin{array}{l}21.6 \\
(1911 / 8829)\end{array}$ & $\begin{array}{l}24.9 \\
(2206 / 8829)\end{array}$ & $\begin{array}{l}16.3 \\
(1298 / 7982)\end{array}$ & $\begin{array}{l}10.8 \\
(961 / 8877)\end{array}$ & $\begin{array}{l}55.8 \\
(3669 / 6579)\end{array}$ & $\begin{array}{l}13.3 \\
(873 / 6579\end{array}$ \\
\hline$-1 S D$ to $-0.01 S D$ & $\begin{array}{l}4.9 \\
(357 / 7286)\end{array}$ & $\begin{array}{l}4.2 \\
(306 / 7286)\end{array}$ & $\begin{array}{l}20.0 \\
(1459 / 7286)\end{array}$ & $\begin{array}{l}24.8 \\
(1803 / 7286)\end{array}$ & $\begin{array}{l}16.1 \\
(1074 / 6665)\end{array}$ & $\begin{array}{l}11.1 \\
(829 / 7462)\end{array}$ & $\begin{array}{l}55.3 \\
(3074 / 5558)\end{array}$ & $\begin{array}{l}12.2 \\
(679 / 5558\end{array}$ \\
\hline OSD to $0.99 S D$ & $\begin{array}{l}4.3 \\
(128 / 2995)\end{array}$ & $\begin{array}{l}4.3 \\
(130 / 2995)\end{array}$ & $\begin{array}{l}19.2 \\
(574 / 2995)\end{array}$ & $\begin{array}{l}27.2 \\
(813 / 2995)\end{array}$ & $\begin{array}{l}14.4 \\
(390 / 2708)\end{array}$ & $\begin{array}{l}11.1 \\
(343 / 3090)\end{array}$ & $\begin{array}{l}53.5 \\
(1237 / 2312)\end{array}$ & $\begin{array}{l}13.3 \\
(307 / 2312\end{array}$ \\
\hline $1 \mathrm{SD}$ to $1.99 \mathrm{SD}$ & $\begin{array}{l}5.6 \\
(45 / 803)\end{array}$ & $\begin{array}{l}4.5 \\
(36 / 803)\end{array}$ & $\begin{array}{l}21.3 \\
(171 / 803)\end{array}$ & $\begin{array}{l}34.4 \\
(276 / 803)\end{array}$ & $\begin{array}{l}18.6 \\
(141 / 757)\end{array}$ & $\begin{array}{l}10.2 \\
(88 / 859)\end{array}$ & $\begin{array}{l}61.7 \\
(398 / 645)\end{array}$ & $\begin{array}{l}17.8 \\
(115 / 645)\end{array}$ \\
\hline 2SD or more & $\begin{array}{l}1.5 \\
(4 / 262)\end{array}$ & $\begin{array}{l}2.7 \\
(7 / 262)\end{array}$ & $\begin{array}{l}19.5 \\
(51 / 262)\end{array}$ & $\begin{array}{l}30.9 \\
(81 / 262)\end{array}$ & $\begin{array}{l}13.9 \\
(34 / 244)\end{array}$ & $\begin{array}{l}7.9 \\
(22 / 277)\end{array}$ & $\begin{array}{l}54.1 \\
(112 / 207)\end{array}$ & $\begin{array}{l}12.1 \\
(25 / 207)\end{array}$ \\
\hline Total & $\begin{array}{l}4.5 \\
(1144 / 25418)\end{array}$ & $\begin{array}{l}4.3 \\
(1082 / 25418)\end{array}$ & $\begin{array}{l}21.7 \\
(5515 / 25418)\end{array}$ & $\begin{array}{l}25.8 \\
(6562 / 25418)\end{array}$ & $\begin{array}{l}16.1 \\
(3721 / 23059)\end{array}$ & $\begin{array}{l}11.0 \\
(2838 / 25814)\end{array}$ & $\begin{array}{l}56.2 \\
(10702 / 19031)\end{array}$ & $\begin{array}{l}13.6 \\
(2588 / 190\end{array}$ \\
\hline $\begin{array}{l}\text { p-value }{ }^{10} \\
\text { (lineart/quadratic) }^{\text {tinea }}\end{array}$ & 0.038 & $0.420^{+}$ & $<0.001^{t}$ & $<0.001$ & $0.25^{t}$ & $0.39 t$ & 0.002 & $<0.001$ \\
\hline $\begin{array}{l}\text { p-value }{ }^{11} \\
\text { (lineart/quadratic) }\end{array}$ & 0.105 & $0.040 t$ & $0.060 t$ & 0.001 & $0.53^{t}$ & $0.43 t$ & 0.034 & 0.010 \\
\hline
\end{tabular}

${ }^{1}$ High total cholesterol (5-19 years) ${ }^{3} 200 \mathrm{mg} / \mathrm{dl}$

${ }^{2}$ High LDL cholesterol (5-19 years) ${ }^{3} 130 \mathrm{mg} / \mathrm{dl}$ 
${ }^{3}$ Low HDL cholesterol (5-19 years) $<40 \mathrm{mg} / \mathrm{dl}$

${ }^{4}$ High triglyceride $(5-9 \text { years })^{3} 100 \mathrm{mg} / \mathrm{dl}$ and $(10-19 \text { years })^{3} 130 \mathrm{mg} / \mathrm{dl}$

${ }^{5}$ High fasting glucose $(5-19$ years $) \geq 100 \mathrm{mg} / \mathrm{dl}$

${ }^{6} \mathrm{High}$ glycosylated haemoglobin ( $5-19$ years) $\geq 5.7 \%$

${ }^{7}$ Presence of at least one $(\geq 1)$ of the above six biomarkers of metabolic obesity.

${ }^{8}$ 2-MetS is defined as presence of two out of three biochemical abnormalities (Dysglycemia, Low HDL cholesterol, High triglyceride).

${ }^{9} 3$-MetS is defined as presence of all three biochemical abnormalities (Dysglycemia, Low HDL cholesterol, High triglyceride).

${ }^{10} \mathrm{p}$-value denoting the unadjusted lineart/quadratic trend by logistic regression analysis.

${ }^{11} \mathrm{p}$-value denoting the lineart/quadratic trend adjusted for age (continuous variable), sex, place of residence and wealth index categories by logistic regression analysis

Table 3: Prevalence of metabolic obesity biomarkers according to socio-demographic characteristics 


\begin{tabular}{|c|c|c|c|c|c|c|c|c|c|}
\hline Characteristic & $\begin{array}{l}\text { High total } \\
\text { Cholesterol } \\
(\%) \\
(\mathrm{n} / \mathrm{N})\end{array}$ & $\begin{array}{l}\text { High LDL } \\
\text { Cholesterol } \\
(\%) \\
(\mathrm{n} / \mathrm{N})\end{array}$ & $\begin{array}{l}\text { Low HDL } \\
\text { Cholesterol } \\
(\%) \\
(\mathrm{n} / \mathrm{N})\end{array}$ & $\begin{array}{l}\text { High } \\
\text { triglyceride } \\
(\%) \\
(\mathrm{n} / \mathrm{N})\end{array}$ & $\begin{array}{l}\text { High fasting } \\
\text { glucose } \\
(\%) \\
(\mathrm{n} / \mathrm{N})\end{array}$ & $\begin{array}{l}\text { High } \\
\text { glycosylated } \\
\text { hemoglobin } \\
(\%) \\
(n / N)\end{array}$ & $\begin{array}{l}\text { At least one } \\
(\geq 1) \\
\text { biomarker of } \\
\text { metabolic } \\
\text { obesity } \\
(\%) \\
(n / N)\end{array}$ & $\begin{array}{l}\text { 2-MetS } \\
(\%) \\
(n / N)\end{array}$ & (n) \\
\hline \multicolumn{10}{|l|}{ Age (years) } \\
\hline $5-9$ & $\begin{array}{l}4.7 \\
(637 / 13618)\end{array}$ & $\begin{array}{l}4.1 \\
(561 / 13618)\end{array}$ & $\begin{array}{l}19.4 \\
(2642 / 13618)\end{array}$ & $\begin{array}{l}33.9 \\
(4624 / 13618)\end{array}$ & $\begin{array}{l}15.7 \\
(1918 / 12200)\end{array}$ & $\begin{array}{l}10.2 \\
(1405 / 13771)\end{array}$ & $\begin{array}{l}58.5 \\
(5861 / 10016)\end{array}$ & $\begin{array}{l}15.3 \\
(1531 / 10016)\end{array}$ & $\begin{array}{l}2 . \\
(2\end{array}$ \\
\hline $10-14$ & $\begin{array}{l}4.4 \\
(310 / 7068)\end{array}$ & $\begin{array}{l}4.1 \\
(289 / 7068)\end{array}$ & $\begin{array}{l}21.5 \\
(1520 / 7068)\end{array}$ & $\begin{array}{l}17.8 \\
(1258 / 7068)\end{array}$ & $\begin{array}{l}17.9 \\
(1168 / 6503)\end{array}$ & $\begin{array}{l}12.4 \\
(894 / 7194)\end{array}$ & $\begin{array}{l}53.5 \\
(2891 / 5405)\end{array}$ & $\begin{array}{l}12.3 \\
(666 / 5405)\end{array}$ & $\begin{array}{l}1 . \\
(6\end{array}$ \\
\hline $15-19$ & $\begin{array}{l}5.0 \\
(308 / 6136)\end{array}$ & $\begin{array}{l}5.5 \\
(340 / 6136)\end{array}$ & $\begin{array}{l}27.3 \\
(1677 / 6136)\end{array}$ & $\begin{array}{l}16.8 \\
(1033 / 6136)\end{array}$ & $\begin{array}{l}15.4 \\
(880 / 5698)\end{array}$ & $\begin{array}{l}10.9 \\
(690 / 6293)\end{array}$ & $\begin{array}{l}55.1 \\
(2595 / 4711)\end{array}$ & $\begin{array}{l}11.8 \\
(558 / 4711)\end{array}$ & $\begin{array}{l}1 . \\
(8\end{array}$ \\
\hline $\begin{array}{l}\text { OR }(95 \% \mathrm{Cl}) \\
\left.\text { [p-value }^{1}\right]\end{array}$ & $\begin{array}{l}1.03(0.96- \\
1.10) \\
{[0.45]}\end{array}$ & $\begin{array}{l}1.15(1.08- \\
1.24) \\
{[<0.001]}\end{array}$ & $\begin{array}{l}1.24(1.20- \\
1.29) \\
{[<0.001]}\end{array}$ & $\begin{array}{l}0.56(0.39- \\
0.61) \\
{[<0.001]}\end{array}$ & $\begin{array}{l}1.01(0.97- \\
1.05) \\
{[0.69]}\end{array}$ & $\begin{array}{l}1.06(1.01- \\
1.11)[0.012]\end{array}$ & $\begin{array}{l}0.92(0.89- \\
0.95)[<0.001]\end{array}$ & $\begin{array}{l}0.85(0.81- \\
0.89) \\
{[<0.001]}\end{array}$ & $\begin{array}{l}0 . \\
0 . \\
{[0}\end{array}$ \\
\hline $\begin{array}{l}\text { OR }(95 \% \mathrm{Cl}) \\
\left.\text { [p-value }{ }^{2}\right]\end{array}$ & $\begin{array}{l}1.03(0.96- \\
1.10) \\
{[0.44]}\end{array}$ & $\begin{array}{l}1.16(1.08- \\
1.24) \\
{[<0.001]}\end{array}$ & $\begin{array}{l}1.24(1.20- \\
1.28) \\
{[<0.001]}\end{array}$ & $\begin{array}{l}0.58(0.56- \\
0.60) \\
{[<0.001]}\end{array}$ & $\begin{array}{l}1.01(0.97- \\
1.05) \\
{[0.66]}\end{array}$ & $\begin{array}{l}1.07(1.02- \\
1.12)[0.008]\end{array}$ & $\begin{array}{l}0.91(0.89- \\
0.94)[<0.001]\end{array}$ & $\begin{array}{l}0.85(0.80- \\
0.89) \\
{[<0.001]}\end{array}$ & $\begin{array}{l}0 . \\
0 . \\
{[0}\end{array}$ \\
\hline Sex & & & & & & & & & \\
\hline Male & $\begin{array}{l}4.4 \\
(614 / 14034)\end{array}$ & $\begin{array}{l}4.0 \\
(557 / 14034)\end{array}$ & $\begin{array}{l}22.3 \\
(3126 / 14034)\end{array}$ & $\begin{array}{l}23.8 \\
(3340 / 14034)\end{array}$ & $\begin{array}{l}17.2 \\
(2195 / 12741)\end{array}$ & $\begin{array}{l}12.3 \\
(1763 / 14334)\end{array}$ & $\begin{array}{l}56.7 \\
(5967 / 10534)\end{array}$ & $\begin{array}{l}13.9 \\
(1463 / 10534)\end{array}$ & $\begin{array}{l}1 . \\
(1\end{array}$ \\
\hline Female (Ref) & $\begin{array}{l}5.0 \\
(641 / 12788)\end{array}$ & $\begin{array}{l}4.9 \\
(633 / 12788)\end{array}$ & $\begin{array}{l}21.2 \\
(2713 / 12788)\end{array}$ & $\begin{array}{l}27.9 \\
(3575 / 12788)\end{array}$ & $\begin{array}{l}15.2 \\
(1771 / 11660)\end{array}$ & $\begin{array}{l}9.5 \\
(1226 / 12924)\end{array}$ & $\begin{array}{l}56.1 \\
(5380 / 9598)\end{array}$ & $\begin{array}{l}13.5 \\
(1292 / 9598)\end{array}$ & $\begin{array}{l}1 . \\
(1\end{array}$ \\
\hline $\begin{array}{l}\text { OR }(95 \% \mathrm{Cl}) \\
\left.\text { [p-value }^{1}\right]\end{array}$ & $\begin{array}{l}0.87(0.77- \\
0.97)[0.014]\end{array}$ & $\begin{array}{l}0.79(0.70- \\
0.89) \\
{[<0.001]}\end{array}$ & $\begin{array}{l}1.06(1.00- \\
1.13) \\
{[0.036]}\end{array}$ & $\begin{array}{l}0.80(0.76- \\
0.85)[<0.001]\end{array}$ & $\begin{array}{l}1.16(1.08- \\
1.24)[<0.001]\end{array}$ & $\begin{array}{l}1.34(1.24- \\
1.45)[<0.001]\end{array}$ & $\begin{array}{l}1.02(0.97- \\
1.08)[0.40]\end{array}$ & $\begin{array}{l}1.03(0.95- \\
1.12) \\
{[0.378]}\end{array}$ & $\begin{array}{l}0 . \\
1 . \\
{[0}\end{array}$ \\
\hline $\begin{array}{l}\text { OR }(95 \% \mathrm{Cl}) \\
\left.\text { [p-value }{ }^{2}\right]\end{array}$ & $\begin{array}{l}0.86(0.77- \\
0.96)[0.01]\end{array}$ & $\begin{array}{l}0.79(0.70- \\
0.89) \\
{[<0.001]}\end{array}$ & $\begin{array}{l}1.08(1.02- \\
1.14) \\
{[0.013]}\end{array}$ & $\begin{array}{l}0.78(0.74- \\
0.83)[<0.001]\end{array}$ & $\begin{array}{l}1.16(1.09- \\
1.25)[<0.001]\end{array}$ & $\begin{array}{l}1.34(1.24- \\
1.45)[<0.001]\end{array}$ & $\begin{array}{l}1.03(0.97- \\
1.09)[0.39]\end{array}$ & $\begin{array}{l}1.03(0.95- \\
1.12) \\
{[0.414]}\end{array}$ & $\begin{array}{l}0 . \\
1 . \\
{[0}\end{array}$ \\
\hline Place of resic & & & & & & & & & \\
\hline Rural (Ref) & $\begin{array}{l}4.2 \\
(651 / 15405)\end{array}$ & $\begin{array}{l}4.0 \\
(620 / 15405)\end{array}$ & $\begin{array}{l}23.3 \\
(3582 / 15405)\end{array}$ & $\begin{array}{l}27.2 \\
(4187 / 15405)\end{array}$ & $\begin{array}{l}16.3 \\
(2237 / 13748)\end{array}$ & $\begin{array}{l}11.4 \\
(1767 / 15513)\end{array}$ & $\begin{array}{l}58.2 \\
(6515 / 11204)\end{array}$ & $\begin{array}{l}14.6 \\
(1637 / 11204)\end{array}$ & $\begin{array}{l}2 . \\
(2\end{array}$ \\
\hline Urban & $\begin{array}{l}5.3 \\
(604 / 11417)\end{array}$ & $\begin{array}{l}5.0 \\
(570 / 11417)\end{array}$ & $\begin{array}{l}19.8 \\
(2257 / 11417)\end{array}$ & $\begin{array}{l}23.9 \\
(2728 / 11417)\end{array}$ & $\begin{array}{l}16.2 \\
(1729 / 10653)\end{array}$ & $\begin{array}{l}10.4 \\
(1222 / 11745)\end{array}$ & $\begin{array}{l}54.1 \\
(4832 / 8928)\end{array}$ & $\begin{array}{l}12.5 \\
(1118 / 8928)\end{array}$ & $\begin{array}{l}1 . \\
(1\end{array}$ \\
\hline $\begin{array}{l}\text { OR }(95 \% \mathrm{Cl}) \\
\left.\text { [p-value }^{1}\right]\end{array}$ & $\begin{array}{l}1.27(1.13- \\
1.42) \\
{[<0.001]}\end{array}$ & $\begin{array}{l}1.25(1.12- \\
1.41) \\
{[<0.001]}\end{array}$ & $\begin{array}{l}0.81(0.77- \\
0.86) \\
{[<0.001]}\end{array}$ & $\begin{array}{l}0.84(0.77- \\
0.89)[0.005]\end{array}$ & $\begin{array}{l}0.99(0.93- \\
1.07)[0.93]\end{array}$ & $\begin{array}{l}0.90(0.84- \\
0.98)[0.010]\end{array}$ & $\begin{array}{l}0.85(0.80- \\
0.89)[<0.001]\end{array}$ & $\begin{array}{l}0.84(0.77- \\
0.91) \\
{[<0.001]}\end{array}$ & $\begin{array}{l}0 . \\
1 . \\
{[0}\end{array}$ \\
\hline $\begin{array}{l}\text { OR }(95 \% \mathrm{Cl}) \\
{\left[\mathrm{p}-\text { value }^{2}\right]}\end{array}$ & $\begin{array}{l}1.07(0.95- \\
1.22)[0.23]\end{array}$ & $\begin{array}{l}1.04(0.92- \\
1.18)[0.54]\end{array}$ & $\begin{array}{l}1.06(0.99- \\
1.13) \\
{[0.11]}\end{array}$ & $\begin{array}{l}0.91(0.85- \\
0.96)[0.002]\end{array}$ & $\begin{array}{l}1.04(0.96- \\
1.12)[0.33]\end{array}$ & $\begin{array}{l}0.88(0.81- \\
0.96)[0.005]\end{array}$ & $\begin{array}{l}0.96(0.89- \\
1.02)[0.14]\end{array}$ & $\begin{array}{l}0.96(0.88- \\
1.05) \\
{[0.424]}\end{array}$ & $\begin{array}{l}1 . \\
1 . \\
{[0}\end{array}$ \\
\hline Wealth Index & & & & & & & & & \\
\hline Poorest (Ref) & $\begin{array}{l}2.1 \\
(41 / 2003)\end{array}$ & $\begin{array}{l}1.7 \\
(34 / 2003)\end{array}$ & $\begin{array}{l}34.0 \\
(681 / 2003)\end{array}$ & $\begin{array}{l}28.4 \\
(569 / 2003)\end{array}$ & $\begin{array}{l}16.8 \\
(307 / 1832)\end{array}$ & $\begin{array}{l}9.6 \\
(185 / 1922)\end{array}$ & $\begin{array}{l}63.2 \\
(855 / 1352)\end{array}$ & $\begin{array}{l}17.7 \\
(239 / 1352)\end{array}$ & $\begin{array}{l}3 . \\
(4\end{array}$ \\
\hline Poor & $\begin{array}{l}3.3 \\
(112 / 3343)\end{array}$ & $\begin{array}{l}3.6 \\
(120 / 3343)\end{array}$ & $\begin{array}{l}28.6 \\
(957 / 3343)\end{array}$ & $\begin{array}{l}29.1 \\
(973 / 3343)\end{array}$ & $\begin{array}{l}16.8 \\
(499 / 2965)\end{array}$ & $\begin{array}{l}12.1 \\
(395 / 3278)\end{array}$ & $\begin{array}{l}62.5 \\
(1419 / 2272)\end{array}$ & $\begin{array}{l}17.1 \\
(388 / 2272)\end{array}$ & $\begin{array}{l}3 . \\
(6\end{array}$ \\
\hline Middle & $\begin{array}{l}4.5 \\
(234 / 5236)\end{array}$ & $\begin{array}{l}4.0 \\
(211 / 5236)\end{array}$ & $\begin{array}{l}24.3 \\
(1272 / 5236)\end{array}$ & $\begin{array}{l}26.2 \\
(1374 / 5236)\end{array}$ & $\begin{array}{l}17.2 \\
(801 / 4669)\end{array}$ & $\begin{array}{l}12.0 \\
(637 / 5308)\end{array}$ & $\begin{array}{l}58.9 \\
(2212 / 3752)\end{array}$ & $\begin{array}{l}15.3 \\
(575 / 3752)\end{array}$ & $\begin{array}{l}2 . \\
(7\end{array}$ \\
\hline
\end{tabular}




\begin{tabular}{|c|c|c|c|c|c|c|c|c|c|}
\hline Characteristic & $\begin{array}{l}\text { High total } \\
\text { Cholesterol } \\
(\%) \\
(\mathrm{n} / \mathrm{N})\end{array}$ & $\begin{array}{l}\text { High LDL } \\
\text { Cholesterol } \\
(\%) \\
(\mathrm{n} / \mathrm{N})\end{array}$ & $\begin{array}{l}\text { Low HDL } \\
\text { Cholesterol } \\
(\%) \\
(n / N)\end{array}$ & $\begin{array}{l}\text { High } \\
\text { triglyceride } \\
(\%) \\
(n / N)\end{array}$ & $\begin{array}{l}\text { High fasting } \\
\text { glucose } \\
(\%) \\
(\mathrm{n} / \mathrm{N})\end{array}$ & $\begin{array}{l}\text { High } \\
\text { glycosylated } \\
\text { hemoglobin } \\
(\%) \\
(\mathrm{n} / \mathrm{N})\end{array}$ & $\begin{array}{l}\text { At least one } \\
(\geq 1) \\
\text { biomarker of } \\
\text { metabolic } \\
\text { obesity } \\
(\%) \\
(\mathrm{n} / \mathrm{N})\end{array}$ & $\begin{array}{l}\text { 2-MetS } \\
(\%) \\
(n / N)\end{array}$ & $\begin{array}{l}3- \\
\text { (\% } \\
\text { (n }\end{array}$ \\
\hline Rich & $\begin{array}{l}5.5 \\
(404 / 7340)\end{array}$ & $\begin{array}{l}4.8 \\
(352 / 7340)\end{array}$ & $\begin{array}{l}18.7 \\
(1373 / 7340)\end{array}$ & $\begin{array}{l}27.1 \\
(1989 / 7340)\end{array}$ & $\begin{array}{l}16.2 \\
(1083 / 6675)\end{array}$ & $\begin{array}{l}9.5 \\
(718 / 7523)\end{array}$ & $\begin{array}{l}55.4 \\
(3101 / 5594)\end{array}$ & $\begin{array}{l}13.0 \\
(729 / 5594)\end{array}$ & $\begin{array}{l}1 . \\
(9\end{array}$ \\
\hline Richest & $\begin{array}{l}5.2 \\
(464 / 8900)\end{array}$ & $\begin{array}{l}5.3 \\
(473 / 8900)\end{array}$ & $\begin{array}{l}17.5 \\
(1556 / 8900)\end{array}$ & $\begin{array}{l}22.6 \\
(2010 / 8900)\end{array}$ & $\begin{array}{l}15.5 \\
(1276 / 8260)\end{array}$ & $\begin{array}{l}11.4 \\
(1054 / 9227)\end{array}$ & $\begin{array}{l}52.5 \\
(3760 / 7162)\end{array}$ & $\begin{array}{l}11.5 \\
(824 / 7162)\end{array}$ & $\begin{array}{l}1 . \\
(1\end{array}$ \\
\hline $\begin{array}{l}\text { OR }(95 \% \mathrm{Cl}) \\
\left.\text { [p-value }^{1}\right]\end{array}$ & $\begin{array}{l}1.19(1.13- \\
1.24) \\
{[<0.001]}\end{array}$ & $\begin{array}{l}1.21(1.15- \\
1.27) \\
{[<0.001]}\end{array}$ & $\begin{array}{l}0.79(0.77- \\
0.81) \\
{[<0.001]}\end{array}$ & $\begin{array}{l}0.92(0.90- \\
0.94)[<0.001]\end{array}$ & $\begin{array}{l}0.97(0.94- \\
0.99)[0.019]\end{array}$ & $\begin{array}{l}0.99(0.97- \\
1.03)[0.92]\end{array}$ & $\begin{array}{l}0.88(0.86- \\
0.90)[<0.001]\end{array}$ & $\begin{array}{l}0.87(0.84- \\
0.89) \\
{[<0.001]}\end{array}$ & $\begin{array}{l}0 . \\
0 . \\
{[<1}\end{array}$ \\
\hline $\begin{array}{l}\text { OR }(95 \% \mathrm{Cl}) \\
\left.\text { [p-value }{ }^{2}\right]\end{array}$ & $\begin{array}{l}1.17(1.11- \\
1.24) \\
{[<0.001]}\end{array}$ & $\begin{array}{l}1.21(1.14- \\
1.28) \\
{[<0.001]}\end{array}$ & $\begin{array}{l}0.78(0.76- \\
0.80) \\
{[<0.001]}\end{array}$ & $\begin{array}{l}0.93(0.90- \\
0.95)[0.001]\end{array}$ & $\begin{array}{l}0.96(0.93- \\
0.99)[0.010]\end{array}$ & $\begin{array}{l}1.02(0.98- \\
1.05)[0.29]\end{array}$ & $\begin{array}{l}0.89(0.87- \\
0.91)[<0.001]\end{array}$ & $\begin{array}{l}0.87(0.84- \\
0.90) \\
{[<0.001]}\end{array}$ & $\begin{array}{l}0 . \\
0 . \\
{[<1}\end{array}$ \\
\hline
\end{tabular}

For definitions of biomarkers of metabolic obesity, please refer to Table 1 or footnotes of Table 2.

${ }^{1} \mathrm{p}$-value for linear trend unadjusted odds ratio by logistic regression analysis with age as continuous variable

${ }^{2} \mathrm{p}$ - value for linear trend odds ratio adjusted for age (continuous variable), sex, residence, and wealth index categories by logistic regression analysis

\section{Figures}

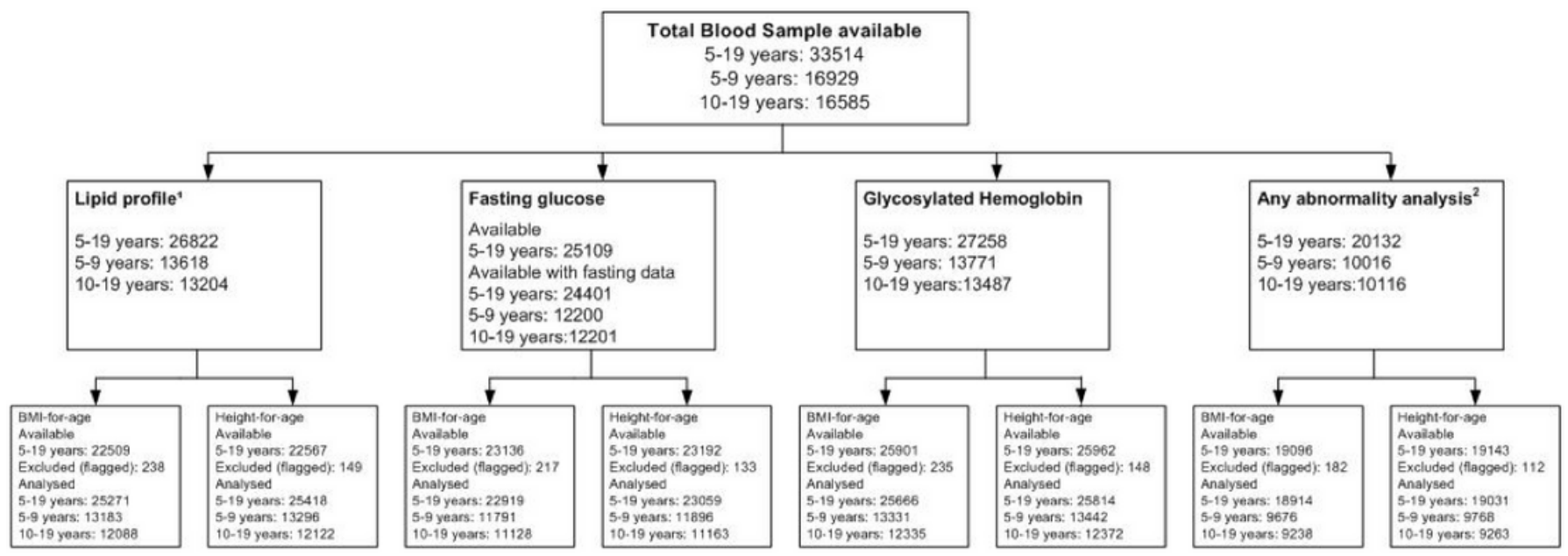

' Lipid profile includes Total Cholesterol, LDL Cholesterol, HDL Cholesterol and Triglyceride

${ }^{2}$ Availability of all laboratory parameters for Lipid profile, Fasting glucose and Glycosylated hemoglobin

\section{Figure 1}

Flow chart depicting the participants analysed for biochemical parameters in relation to arthrometric indices. 

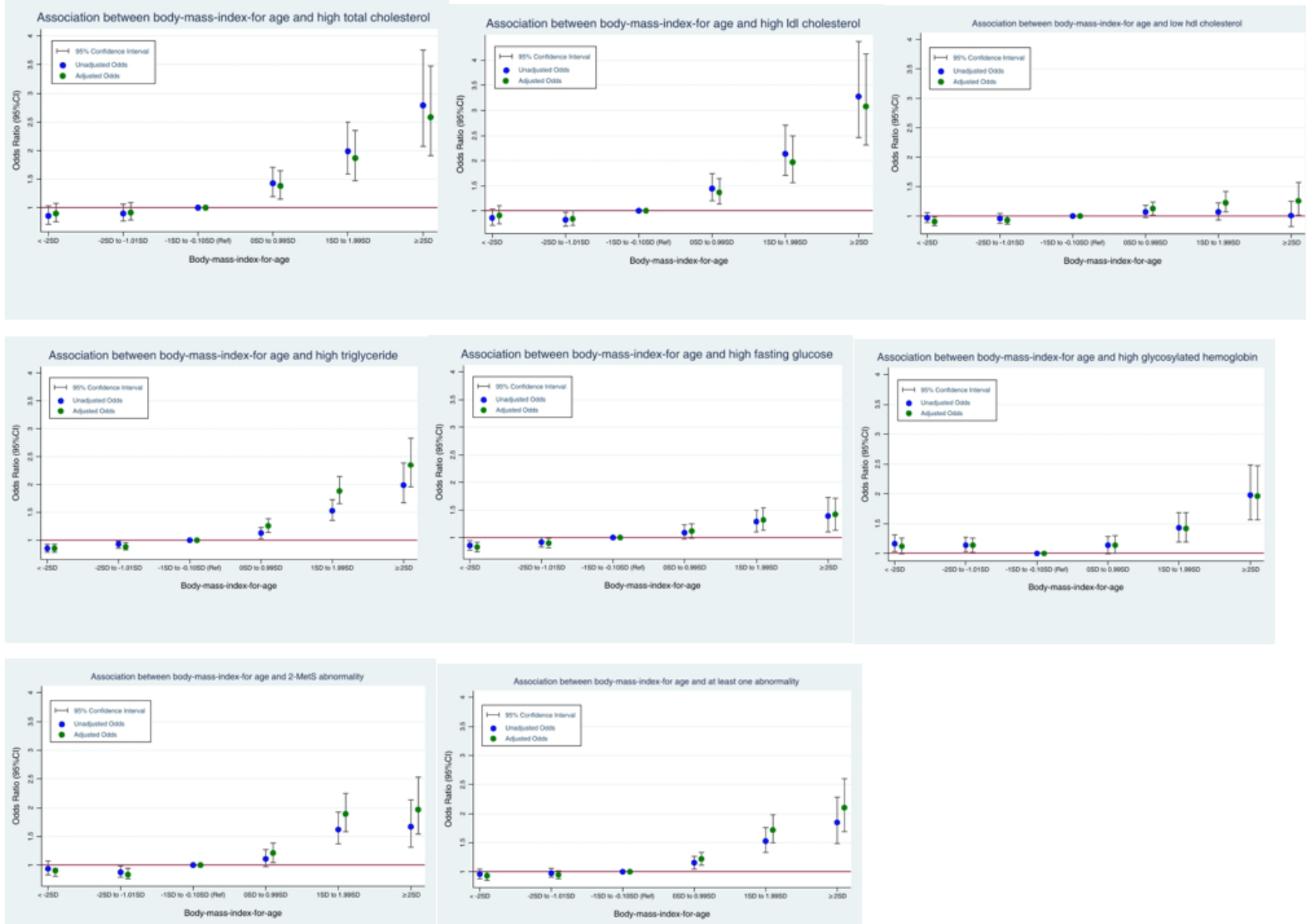

\section{Figure 2}

Presence of metabolic obesity biomarkers in relation to BMI-for-age categories among 5-19 years old children. 

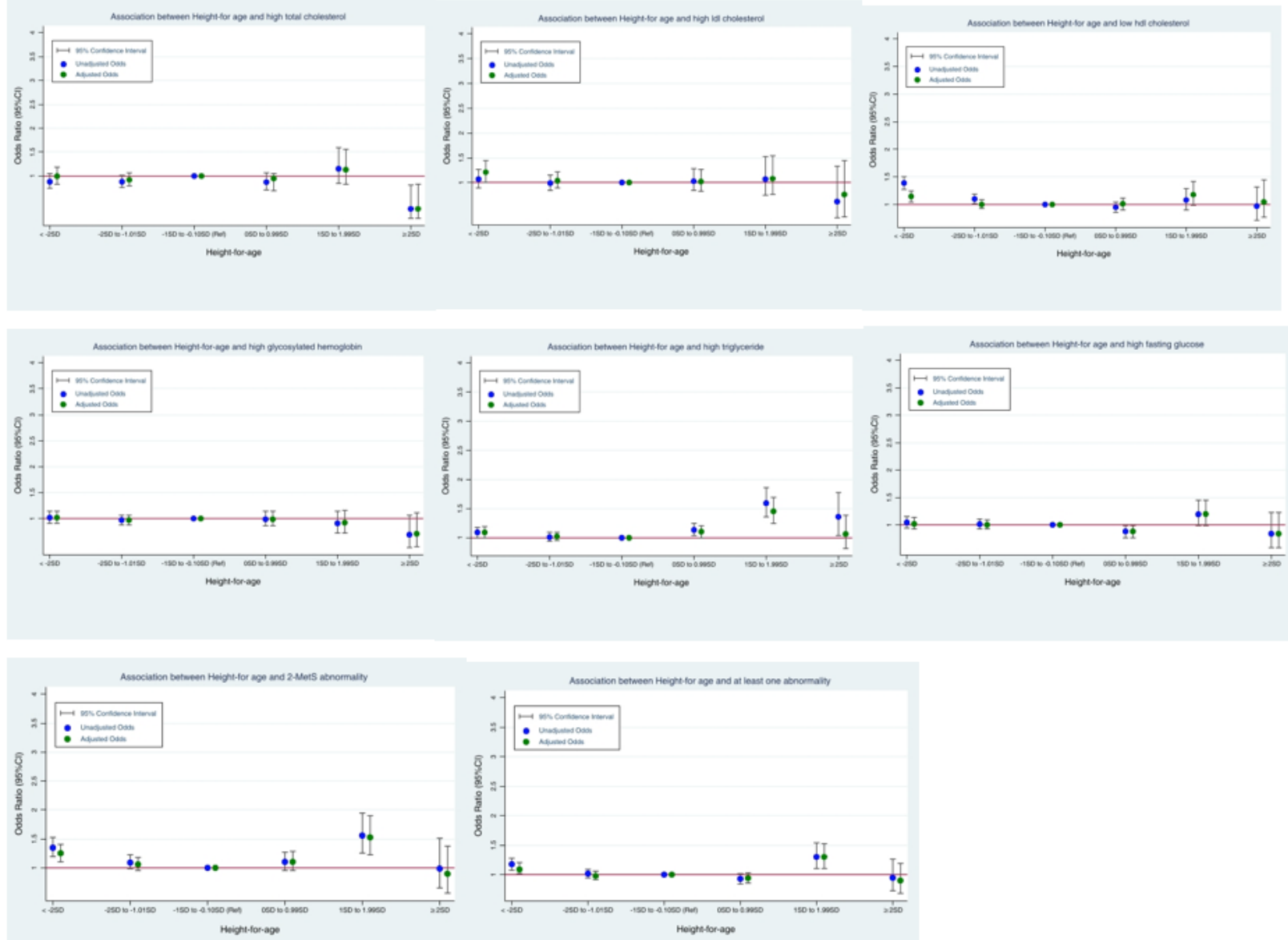

Figure 3

Presence of metabolic obesity biomarkers in relation to height-for-age categories among 5-19 years old children.

\section{Supplementary Files}

This is a list of supplementary files associated with this preprint. Click to download.

- SupplementTables.docx

- SupplementTables.docx 